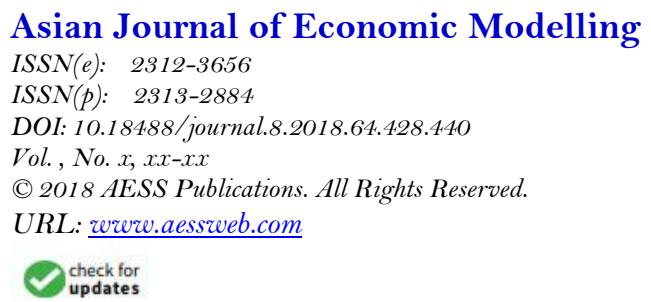

\title{
SOCIOECONOMIC STABILITY AND VARIABILITY IN STOCK MARKET PRICES: A CASE STUDY OF KARACHI STOCK EXCHANGE
}

\author{
Rafaqat Ali ${ }^{1}$ \\ Rana Ejaz Ali Khan ${ }^{2+}$
}

\author{
'Visiting Lecturer, Department of Economics The Islamia University of \\ Bahawalpur, Bahawalpur, Pakistan \\ 'Associate Professor and Chairman, Department of Economics The Islamia \\ University of Bahawalpur, Bahawalpur, Pakistan \\ Email: ranaeja alitihan@yahoo.com
}

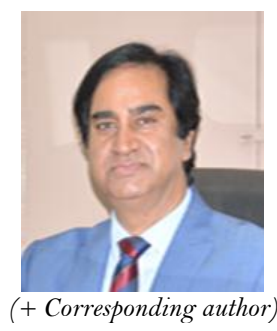

ABSTRACT

The study attempted to identify the factors that responsible for variability in stock market prices in Karachi Stock Exchange particularly focusing on socioeconomic stability in the country. The socioeconomic stability is measured by an index including social, economic and political dimensions of stability. Annual time series data for the years 1973-2012 is utilized, and Phillips \& Perron (PP) test is employed for stationarity. Autoregressive Conditional Heteroscedasticity and Generalized Conditional Heteroscedasticity (ARCH/GARCH) technique are used for volatility in stock market prices. For the structural breaks, Chow test is applied. Finally, the study utilized the Autoregressive Distributed Lag (ARDL) approach to estimate the long-run and short-run dynamic relationship. The results indicate that inflation, exchange rate, and foreign direct investment positively influence the stock price volatility. Socioeconomic stability negatively affects the volatility in stock market prices in both short-run and long-run. The country should improve socioeconomic stability by attaining economic, social and political standards in the country.

Contribution/ Originality: This paper contributes in the literature by investigating the impact of socioeconomic stability on stock market prices in Karachi Stock Exchange and creating an index of 12 indicators. The index comprised of economic, social and political dimensions.

\section{INTRODUCTION}

In the last two decades, the study of stock market has remained a hot area of research in economics and finance. The stock market is assumed an effective tool in economic activity and growth. It generates capital for businesses, converting idle savings into productive investment, creating opportunities for investment and raising the employment level of the economies. The world has become a global village. A product from one part of the world has access to everywhere with little restriction as compared to a few decades ago. Similarly an event in an economy can disturb another economy as well as the whole world. For example the incidence of 9/11 not only disturbed the US economy but it also affected the whole world. Similarly, Osama's death affected the financial market in a single day not only in Pakistan but in developed world also.

Stock exchanges play a central role in an economy as a source of long-term funding to the firms. Developed countries know the importance of generating capital and its utilization while developing countries has less 
inclination to raise the capital. It may be due to the low per-capita income, low saving rate, high expenditure on traditions, conservativeness of people, lack of awareness, economic and political instability and underutilization of resources.

Stock market price is the most important indicator for the investors for their decision making for investment in the stock market, while the fluctuations in stock market prices are irregular and unpredictable (Grossman and Shiller, 1981). Unpredictability is a good sign of well-functioning of stock market. However, the movements of stock market prices are result of national and global political and economic events and variability in stock prices is not good for the development of capital market.

The growing association between stock price volatility and macroeconomic variables in developed as well as developing countries has been discussed in literature. A number of studies have attempted to find out the determinants of stock price variability for developed countries (Mukherjee and Naka, 1995; Beaulieu et al., 2005; Gan et al., 2006; Humpe and Macmillan, 2007). Literature also existed for developing countries including Pakistan (Menike, 2003; Ali, 2011; Asaolu and Ogunmuyiwa, 2011; Azam, 2011; Azam and Kumar, 2011; Rukh et al., 2011; Akbar et al., 2012). For Pakistan none of the studies have captured the effect of socioeconomic stability on stock market prices.

The variation in stock prices is attributed to macroeconomic variation and socioeconomic instability. Pakistan has experienced almost all types of political controls from democracy to presidential and army rule. Having the atomic power, islamisation of the economy and war against terrorism has remained part of the socioeconomic scenario of the country. Such type of changes tones the market direction. If there is stable political and socioeconomic setup positive response comes from investors which stimulate growth of the stock market and the economy. On the other hand if instability exists stock market shrinks and economic growth goes down. Socioeconomic instability has adverse effect on the stock market performance.

The distinctive feature of the current paper is that it has attempted to see the impact of political, economic and social stability on the stock market prices by socioeconomic stability index. Theoretically it is based on Efficient Market Hypothesis (EMH) which explains that stock market prices are fluctuated by some fundamental macroeconomic indicators (Fama, 1970; 1990).

\section{METHODOLOGY}

The objective of the study is to estimate the determinants of variability in stock market price particularly focusing on socioeconomic stability. The functional form of the theoretical model is given as:

$$
\mathrm{VSP}=\mathrm{f}(\mathrm{FDI}, \mathrm{EXR}, \mathrm{GDPD}, \mathrm{SSI})
$$

Where

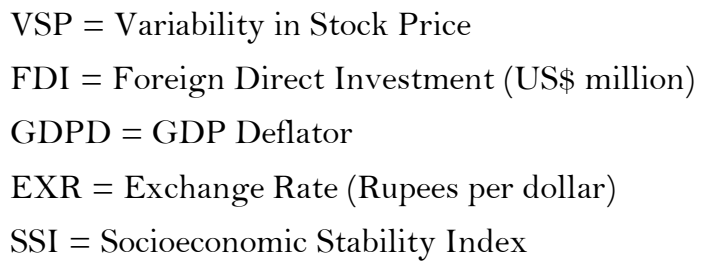

Annual time series data for the years 1973 to 2012 has been taken from State Bank of Pakistan, Pakistan Bureau of Statistics, Pakistan Economic Survey, Hand Book of Statistics on Pakistan Economy and World Bank. Stationarity of data has been checked by Phillips and Perron test and volatility in stock price is measured by GARCH model. Finally ARDL to co-integration test is applied to measure the short run and long relationship. 


\subsection{Socioeconomic Stability Index}

The socioeconomic stability of the economy is measured by an index with three dimensions namely economic, social and political. The index is constructed by additive method including economic, social and political indicators of Pakistan economy. The indicators and dimensions are expressed in table 1 and 2.

Table-1. Measuring the Dimensions and Indicators of Socioeconomic Stability Index

\begin{tabular}{|c|c|c|c|}
\hline Index & Dimension & Indicators & Measurement \\
\hline \multirow{12}{*}{ 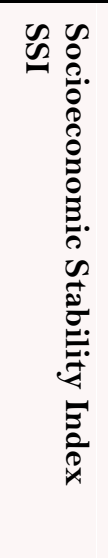 } & \multirow{4}{*}{ Economic Stability } & GDP per capita & GDP per capita* \\
\hline & & Total reserves & Total reserves including gold, current $\mathrm{US}^{*} *$ \\
\hline & & Inequity & Gini Index***** \\
\hline & & employment rate & 1 - Unemployment rate***** \\
\hline & \multirow[t]{6}{*}{ Social Stability } & Tourist arrival in Pakistan & Tourist arrival in Pakistan per year in thousands** \\
\hline & & Trademark applications & Total trademark applications in year** \\
\hline & & Films released & Total Urdu feature films released in a year*** \\
\hline & & Labor union & Total labor unions registered in a year. ${ }^{* *}$ \\
\hline & & Crimes reported & $\begin{array}{l}\text { Total first inquiry reports (FIRs) in police stations in } \\
\text { a year** }\end{array}$ \\
\hline & & Supreme court petition & Total Supreme court petition in year** \\
\hline & \multirow[t]{2}{*}{ Political Stability } & Regime Type & $\begin{array}{l}\text { If elected members }=1 \text {, otherwise (dictatorship) }= \\
\mathrm{O}^{* * *}\end{array}$ \\
\hline & & War & If war $=0$, otherwise $=1 * * *$ \\
\hline & les & $\begin{array}{l}\text { orld Bank) } \\
\text { (Various issues) } \\
\text { Zaidi (2010) }\end{array}$ & \\
\hline
\end{tabular}

Table-2. Conceptual framework of Economic Stability Index ${ }^{1}$

\begin{tabular}{|c|c|c|c|}
\hline Main Pillar & Sub Pillar & Indicators & Desired Direction \\
\hline \multirow{12}{*}{$\begin{array}{l}\text { Socioeconomic } \\
\text { Stability }\end{array}$} & \multirow{4}{*}{ (1/3) Economic Stability } & (1/4) GDP per capita & + \\
\hline & & (1/4)Income Equality & + \\
\hline & & (1/4) Total Reserves & + \\
\hline & & (1/4) Employment rate & + \\
\hline & \multirow{6}{*}{$(1 / 3)$ Social Stability } & $(1 / 6)$ Tourist arrival & + \\
\hline & & (1/6) Crime Reported & - \\
\hline & & (1/6) Supreme Court Petitions & - \\
\hline & & (1/6) Trade mark application registered & + \\
\hline & & (1/6) Labor union registered & + \\
\hline & & (1/6) Film released (Urdu feature) & + \\
\hline & \multirow{2}{*}{ (1/3) Political Stability } & $(1 / 2)$ Regime type & $\begin{array}{l}\text { Democratic }(+) \\
\text { Dictator }\end{array}$ \\
\hline & & $(1 / 2) \mathrm{War}$ & $\begin{array}{ll}\text { War } & (-) \\
\text { No war } & (+)\end{array}$ \\
\hline
\end{tabular}

The first dimension of the index is economic stability. It is measured by four real economic variables, i.e. GDP per capita at purchasing power parity, income inequality, total reserve and employment rate. The second dimension of the index is social stability which is measured by six indicators like tourist arrivals in Pakistan, crimes reported, Supreme Court petitions, films released, trademark applications and labor union registration. The third dimension of index measures political stability. It is consisted of two indicators, i.e. (i) regime type which shows that ruler is democratic or dictator, (ii) war (war fought by Pakistan army) as a dummy variable.

The data of all variable is normalized by using the following formula.

$$
\text { Index Value }=\frac{X t-X \min }{X \max -X \min }
$$

$X t$ indicates current value of the variable, Xmin indicates minimum value and Xmax indicates maximum value of the variable. By using the above formula, all values are rounded between zero and one. Taking averages of the

${ }^{1}$ See Rotberg and Gisselquist (2009) and Khan and Ullah (2014). 
three dimensions we get the final index value. Zero or close to zero means economic instability and one stands for perfect stability in the economy. The socioeconomic stability index has been shown in figure 1.

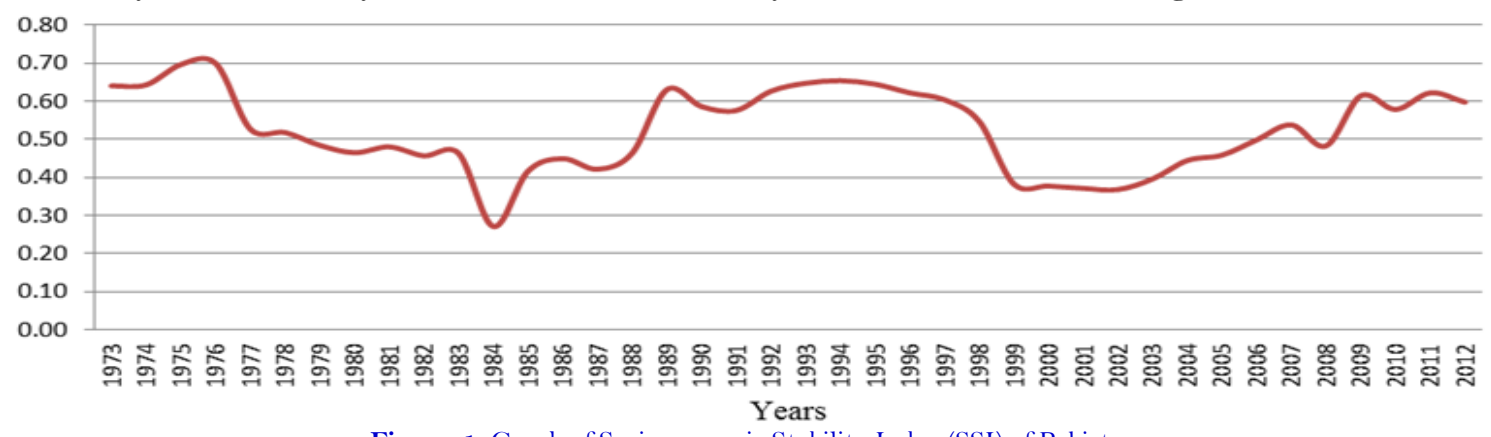

Figure-1. Graph of Socioeconomic Stability Index (SSI) of Pakistan

The response variable of this study is the variability of stock prices (VSP). Stock price index ${ }^{2}$ has been constructed by using the formula:

$$
\text { Stock Price Index }=\frac{\text { CurrentYear Capitalization }}{\text { Base Year Capitalization }} \times 100
$$

Capitalization of the market is the overall market value of all ordinary shares in Karachi Stock Exchange. Karachi Stock Exchange is a representative stock market in Pakistan. The formulation of this index is same as KSE100 index except that it takes into account all ordinary shares quoted on Karachi Stock Exchange.

The variability of stock prices is measured by ARCH/GARCH model.

\subsection{Estimation Techniques}

\subsubsection{Phillips and Perron (PP) Test of Unit Root}

The study used PP test (Phillips and Perron, 1988) because it is non-parametric in nature and corrects serial correlation and heteroscedasticity in error terms. Mathematically PP test is approximately same as Augmented Dickey Fuller (ADF) test that is with and without constant and trend. Normally ADF and PP tests provide the same results regarding order of integration. If the Ho is rejected, then the variable is said stationary or ind ependent of time. If the Ho is not rejected then the variable is said non-stationary or has time effect.

\subsection{Autoregressive Conditional Heteroscedasticity [ARCH (q)] Model}

Autoregressive Conditional Heteroscedasticity (ARCH) technique was projected by Engle (1982) which focuses on the modeling of conditional variance and more appropriately conditional Heteroscedasticity. ARCH model is used to measure the conditional variability or volatility that includes the lagged value and gives higher weights to recent past observations than others. For example the model gives unequal weights formation that changes towards autoregressive method.

\subsection{Generalized Autoregressive Conditional Heteroscedasticity [GARCH p q] Model}

The Generalized ARCH model includes the lagged conditional variance terms as autoregressive. The GARCH model was represented by Bollerslev (1986). We generated conditional variance series and then standard deviation series that represent the volatility in the respective variables.

\footnotetext{
2 The main difference between stock price index and KSE-100 index is that stock price index is calculated with base value of 100 but later is estimated with base value of 1000. Another difference is that KSE-100 index covers top 100 listed companies in Karachi Stock Exchange but stock price index includes all companies in KSE. Furthermore, KSE-100 was started in November, 1991.
} 


\subsection{Autoregressive Distributed Lag (ARDL) Approach to Co-integration}

The present study employs the Autoregressive Distributed Lag (ARDL) approach to co-integration that was projected by Pesaran et al. (2001). A series of lagged independent variables through auto time adjustment process is taken by ARDL approach which is one of the main features of this approach. This approach estimates the conditional ARDL model for dependent variable and explanatory variables.

\subsection{Operations in ARDL Model (Lag and Difference Operation)}

If the objective is to check the dynamics then it is useful to employ the lag operator $(\mathrm{L})$ which is also identified as the backward shift of (II) operator.

\subsection{First Order ARDL Model $(1,1)$}

General form of ARDL equation is as under:

$$
\Delta \mathrm{Y}_{\mathrm{t}}=\alpha_{0}+\sum_{k=i}^{n} \propto \operatorname{yi} \Delta \mathrm{Y}(\mathrm{t}-\mathrm{i})+\sum_{k=i}^{n} \partial \operatorname{yi} \Delta \mathrm{Xi}\left((\mathrm{t}-\mathrm{i})+\delta_{\mathrm{i}} \mathrm{y} \mathrm{Xi}_{(\mathrm{t})}\right.
$$

ARDL approach has two major steps. First step is to test the long run relationship among the variables. F-test is used for checking the long-run association between the variables. Pesaran and Shin (1999) and Pesaran et al. (2001) found two sets of critical values: first set assumes that all variables are cointegrated at order I(1). The second set assumes the variables are integrated at I (O) at given level of significance. These two sets are said upper critical bound and lower critical bound. If F-statistic is greater than upper critical bounds than co-integration relationship exists. If $\mathrm{F}$ statics is lower than lower critical bound than there is no co-integration. If $\mathrm{F}$-static is between upper and lower critical bound then the results are inconclusive.

The second step involves the estimation of long run and short run relationship among the variables. For short run relationship following model of ECM is taken into consideration.

Error Correction model equation is given as:

$$
\Delta \mathrm{Y}_{\mathrm{t}}=\alpha_{0}+\sum_{k=\mathrm{i}}^{n} \propto \mathrm{iy} \Delta \mathrm{Y}(\mathrm{t}-\mathrm{i})+\sum_{k=i}^{n} \partial \mathrm{iy} \Delta \mathrm{Xi}(\mathrm{t}-\mathrm{i})+\delta \mathrm{ECM}_{\mathrm{t}-1}+\mu_{\mathrm{t}}
$$

By taking lag of dependent variable and take it as an independent variable, we measure the short run relationship as

$$
\begin{aligned}
& \Delta \mathrm{VSP}_{\mathrm{t}}=\alpha_{0}+\sum_{k=i}^{n} \propto \mathrm{i} \Delta \mathrm{VSP}(\mathrm{t}-\mathrm{i})+\sum_{k=i}^{n} \partial \mathrm{i} \Delta \mathrm{FDI}(\mathrm{t}-\mathrm{i})+\sum_{k=i}^{n} \phi^{\mathrm{i}} \Delta \mathrm{EXR}(\mathrm{t}-\mathrm{i}) \sum_{k=i}^{n} \phi_{\mathrm{i}}^{\mathrm{i}} \Delta \mathrm{GPD}(\mathrm{t}-\mathrm{i}) \\
& +\sum_{k=i}^{n} \operatorname{Di}^{\mathrm{i} \Delta S I\left(\mathrm{t}_{-\mathrm{i})}\right.}+\delta \mathrm{ECM}+\mu_{\mathrm{t}} \ldots \ldots \text { (3) }
\end{aligned}
$$

To determine the goodness of fit of the ARDL model, diagnostic tests are constructed. Normality of data, serial correlation, functional form, and heteroscedasticity are checked by diagnostic test. This test used the cumulative sum residuals (CUSUM) and the cumulative sum of squares of recursive residuals (CUSUMSQ) to measure the stability of the model with the help of graphs. If the estimated line of CUSUM and CUSUM square remain inside the critical bounds (upper bound and lower bound) of $5 \%$, then the model is called statistically stable otherwise instable.

\subsection{Chow Test of Structural Breaks}

In time series data, there is a possibility of structural changes in the relationship between dependent variable and independent variables. Structural change means that parameter values of the model do not remain the unchanged throughout all time period. Sometime the structural change comes due to sudden shocks or any other 
external factor changes for example sudden political changes in Pakistan like change of government in 1999 and 9/11 attacks on world trade center. To find the structural break we applied the Chow test.

Null hypothesis of chow test is that there is no structural break in a specific time. If calculated value of $\mathrm{F}$ is greater than critical table value, we reject null hypothesis and accept alternate hypothesis.

\section{RESULTS AND DISCUSSIONS}

\subsection{Descriptive Statistics}

The relationship between stock prices with independent variables has been observed in the course of descriptive analysis. The descriptive statistics are shown in the table-3.

Table-3. Summary of Descriptive Statistics Analysis

\begin{tabular}{l|l|l|l|l|l}
\hline Variable Statistics & VSP & FDI & GDPD & EXR & SSI \\
\hline Mean & 225137.3 & 1031.27 & 51.68 & 36.62 & 0.523 \\
\hline Median & 107015.6 & 322.50 & 28.09 & 28.10 & 0.549 \\
\hline Maximum & 1729803 & 8536.80 & 205.31 & 93.39 & 0.654 \\
\hline Minimum & 299.97 & 6.30 & 5.45 & 9.90 & 0.263 \\
\hline Std. Dev. & 336114 & 1830.61 & 53.21 & 25.84 & 0.103 \\
\hline Skewness & 3.05 & 2.58 & 1.47 & 0.63 & -0.430 \\
\hline Kurtosis & 12.54 & 9.46 & 4.33 & 2.15 & 2.118 \\
\hline Jarque-Bera & 208.73 & 111.43 & 17.06 & 3.80 & 2.528 \\
\hline Probability & 0.000 & 0.000 & 0.000 & 0.14 & 0.282 \\
\hline Sum & 8780354 & 40219.77 & 2015.07 & 1428.26 & 20.92 \\
\hline Observation & 39 & 39 & 39 & 39 & 39 \\
\hline
\end{tabular}

Descriptive statistics show the mean value and standard deviation of the variables. The skewness shows that all the variables are positively skewed except SSI that is negatively skewed. Jarque-Bera (JB) test is applied to check the normality of data. JB statistics with probability (p- values) is used to check the normality of data. P- Values of statistics show that mostly variables are rejected at 5\% level of significance except SSI and EXR, which are significant at 14 and 28 percent respectively. We will use ARDL to cointegration technique that removes the normality issue in the data.

\subsection{Unit Root Estimation}

Phillips and Perron unit root test has been applied for unit root. The results are shown in table 4.

Table-4. Results of Unit Root Phillips and Perron (PP) Test

\begin{tabular}{|c|c|c|c|c|c|}
\hline \multirow{4}{*}{ Variable } & \multicolumn{4}{|l|}{ PP statistics } & \multirow{4}{*}{ Conclusion } \\
\hline & \multicolumn{4}{|c|}{$H_{\text {o: }}$ The variable has a unit root } & \\
\hline & \multicolumn{2}{|l|}{ Level } & \multicolumn{2}{|l|}{$1^{\text {st }}$ difference } & \\
\hline & Adjusted t- statistics & Probability & Adjusted t- statistics & Probability & \\
\hline VSP & -2.3183 & 0.0262 & -5.4822 & 0.0000 & $\mathrm{I}(1)$ \\
\hline FDI & -0.3196 & 0.7510 & -2.4820 & 0.0179 & $\mathrm{I}(1)$ \\
\hline GDPD & -8.4458 & 0.0000 & -2.7600 & 0.0090 & $\mathrm{I}(\mathbf{0})$ \\
\hline EXR & 2.9468 & 0.0055 & -3.5823 & 0.0010 & $\mathrm{I}(\mathbf{1})$ \\
\hline SSI & -2.2018 & 0.3409 & -6.7143 & 0.0000 & $\mathrm{I}(\mathbf{1})$ \\
\hline
\end{tabular}

The test show the unit root of each variable at level with intercept and then at first difference. All the variables are found stationary at $1^{\text {st }}$ difference except GDPD.

\subsection{Estimation of ARCH Model for Variability in Stock Prices}

The first step to measure variability of stock prices is to see the previous value effect on stock prices. For the purpose lagged value effect of stock prices has been estimated. The results are shown in table 5. 
Table-5. Lagged Value Effect of Stock Prices Using OLS

Dependent variable : VSP (Stock prices)

Method: Least Squares

Sample (adjusted): 19732012

Mean Equation

\begin{tabular}{l|l|l|l|l}
\hline Variable & Coefficient & Std. Error & z-Statistic & Probability \\
\hline $\mathrm{C}$ & 1215.0609 & 102.2319 & 1.125489 & 0.2680 \\
\hline $\mathrm{VSP}(-1)$ & $0.991400 \quad 0.059672$ & 16.61427 & 0.0000 \\
\hline R-squared $=0.887472$ & Adjusted R-squared $=0.884257$ & \\
\hline
\end{tabular}

The result found a highly significant impact of previous stock period prices on current prices. We take this step to check the existence of $\mathrm{ARCH}$ effect that is the series has larger or smaller fluctuations. The volatility of stock market prices are expressed by plotting the values in graph. The graph of the series has been shown in figure 2 .

SP

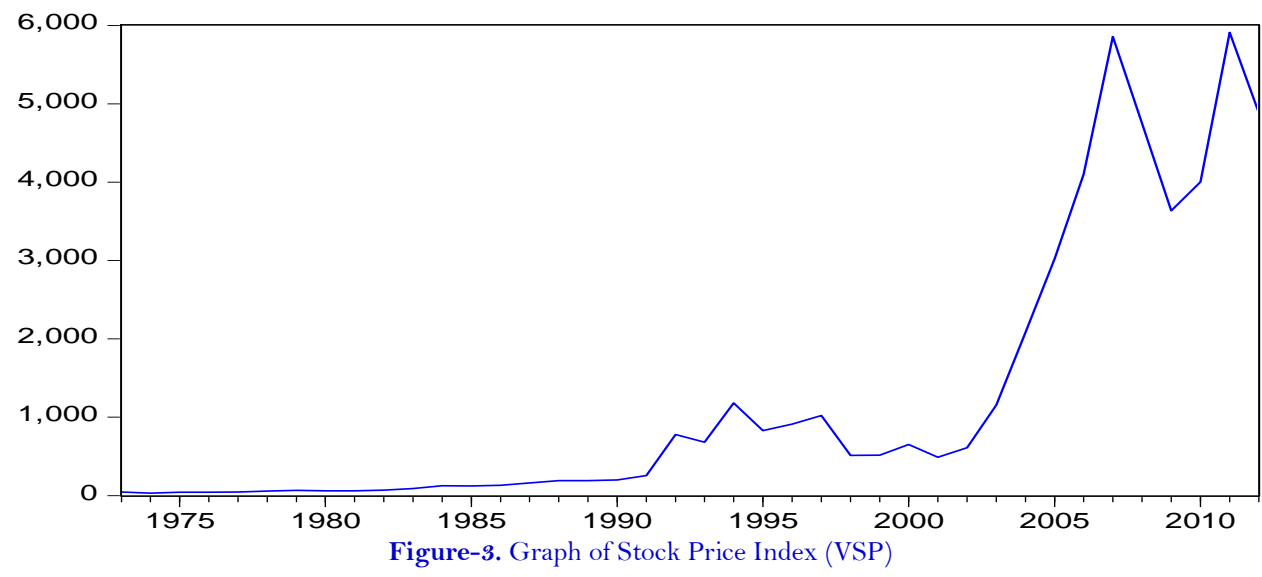

The graph represents the periods of larger and smaller variability in the time series. From 1973 to 1990 , there is no significant volatility in stock prices. After 1990 due to financial reforms in Pakistan and growth of financial sector in 1991, the domestic and foreign investors invest their savings in capital market which pushed stock prices upward. In 2000s a large upward change is observed. It may be due to the effect of $9 / 11$ attacks after which overseas Pakistanis shifted their capital to Pakistan.

We have checked the ARCH effect in data. The results of the ARCH effect are shown in table 6 .

Dependent variable : RESID ${ }^{\wedge 2}$

Table-6. ARCH Effect test

Method: Heteroscedasticity Test: ARCH

Sample (adjusted): 19732012

\begin{tabular}{|c|c|c|c|c|}
\hline F-statistic & 25.58463 & Prob. F(1,34) & 0.0000 & \\
\hline Obs*R-squared & 15.45779 & Prob. Chi-Square(1) & 0.0001 & \\
\hline Variable & Coefficient & Std. Error & t- value & Probability \\
\hline $\mathrm{C}$ & 91804.68 & 80583.63 & 1.139247 & 0.2626 \\
\hline $\operatorname{RESID}^{\wedge} 2(-1)$ & 0.654490 & 0.129394 & 5.058125 & 0.0000 \\
\hline $\begin{array}{l}\text { R-square }=0.429383 \\
2.081608\end{array}$ & \multicolumn{3}{|c|}{ Adjusted R-square $=0.412600$} & Durbin-Watson stat. = \\
\hline
\end{tabular}

The results in table 6 show that there is existence of $\mathrm{ARCH}$ effect in error term. The value $\mathrm{T}^{*} \mathrm{R}^{2}\left(\mathrm{Obs}^{*} \mathrm{R}-\right.$ squared) static is 15.45 with probability of 0.0001 suggesting rejection of null hypothesis of homoskedasticity and the presence of ARCH effect is ensured in the residuals. For volatility, we get a series of conditional variance. For the purpose, ARCH model is used. We regress stock prices on lagged value again through auto regressive conditional heteroscedasticity $(\mathrm{ARCH})$ model. 
Table-7. Summary of ARCH Model

Dependent variable : SP (Stock prices)

Method: ML - ARCH (Marquardt) - Normal distribution

$\mathrm{GARCH}=\mathrm{C}(3)+\mathrm{C}(4)^{*} \mathrm{RESID}(-1)^{\wedge} 2+\mathrm{C}(5)^{*} \mathrm{GARCH}(-1)$

Mean Equation

\begin{tabular}{l|l|l|l|l}
\hline Variable & Coefficient & Std. Error & z-Statistic & Probability \\
\hline C & 87.12801 & 156.0749 & 0.55825 & 0.5765 \\
\hline SP $(-1)$ & 1.012569 & 0.218387 & 4.636579 & 0.0000 \\
\hline Varian
\end{tabular}

\begin{tabular}{l|l|l|l|l}
\hline Variance Equation & 181280.9 & 81769.48 & 2.216975 & 0.0266 \\
\hline $\mathrm{C}$ & 0.526316 & 0.577909 & 0.910724 & 0.3624 \\
\hline RESID $(-1)^{\wedge} 2$ & 0.508994 & 0.824894 & 1.617042 & 0.2572 \\
\hline RESID $(-2)^{\wedge} 2$ & 0.445765 & 0.212506 & 2.097658 & 0.0312 \\
\hline RESID $(-3)^{\wedge} 2$ & 0.308033 & 0.256818 & -1.199422 & 0.1304 \\
\hline GARCH(-1) & -0.787624 & -3.213494 & 0.0002 \\
\hline GARCH(-2) & Adjusted R-square $=0.876014$ & \multicolumn{2}{c}{ Durbin-Watson stat $=1.606$} \\
\hline R-square $=0.879458$
\end{tabular}

R-square $=0.879458 \quad$ Adjusted R-square $=0.876014$

In $\mathrm{ARCH}$ model, the mean equation is summarized as an autoregressive moving average (ARMA) method. It shows that dependent variable is a linear combination of its lagged values. The results show that the value of lagged coefficient is 1.012569 that is greater than zero which means that variability was high in previous period and it will continue to be high in current period. The lagged values of SP are highly significant with p-value of o.0oO showing its impact on current prices.

In the second part of table, variance equation is summarized. In variance equation $\operatorname{RESID}(-1)^{\wedge 2}, \operatorname{RESID}(-2)^{\wedge 2}$ and RESID (-3)^2 are representing ARCH terms and the GARCH $(-1)$ is representing GARCH values. We generate the conditional variance series data from this method that shows variability in stock prices. The graph of conditional variance has been shown in figure 3.

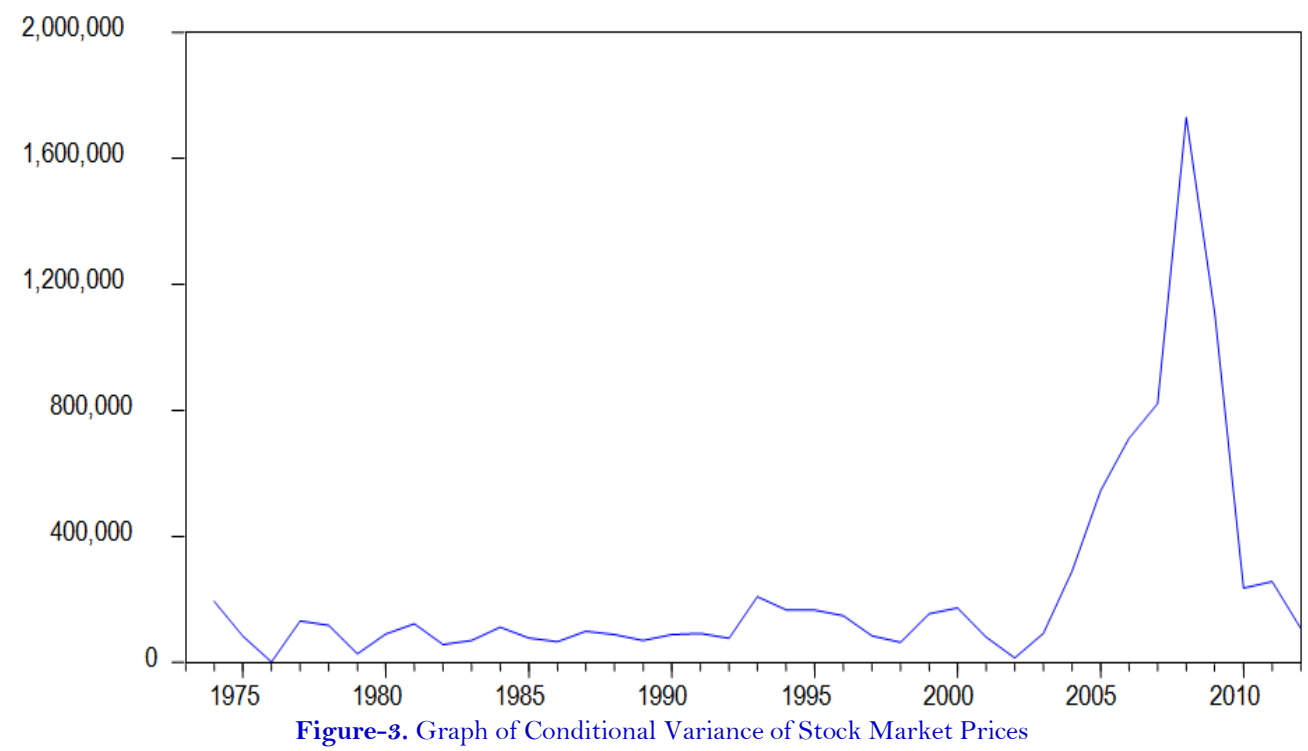

Conditional variance series of residuals is much more specified measure of volatility. We see that from the year 1973 to 1991 the stock prices remained stable in Pakistan, no major change has been occurred. As the period of financial reforms is initiated in the country, the volatility in stock prices occurred, i.e. stock prices started to fluctuate. After 2004 structural breaks in conditional data is found that is checked by chow test of stability. Conditional variance series of data is generated that shows the variability of stock prices. It has been used for further analysis of long run relationship of cointegration. 


\subsection{ARDL to Co-Integration Results}

To determine the short run and long run relationship between the variables, we use ARDL estimation. The estimates of ARDL are obtained on the basis of Schwarz Bayesian Criterion.

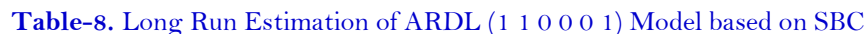

\begin{tabular}{l|l|l|l}
\hline Variables & Coefficients & t- statistics & p-values \\
\hline FDI & 0.0002 & $3.168^{*}$ & 0.003 \\
\hline EXR & -0.037 & $-2.536^{* *}$ & 0.016 \\
\hline GDPD & 0.0047 & $0.964^{*}$ & 0.342 \\
\hline SSI & -0.760 & $-1.997^{* * *}$ & 0.096 \\
\hline Trend & 0.0731 & 3.526 & 0.001 \\
\hline *,** and *** represents $1 \%, 5 \%$ and $10 \%$ level of significance respectively
\end{tabular}

The results in table 8 explain that inflation, foreign direct investment, exchange rate, socioeconomic stability index has significant long run impact on the variability in stock market prices. Inflation and foreign direct investment are found positively affecting the variability in stock prices. Exchange rate and socioeconomic stability has negative effect on variability of stock market prices in Pakistan. It means that socioeconomic stability leads to reduce the variations in stock prices in the long-run.

Diagnostic tests for serial correlation, normality, heteroscedasticity and functional form are applied and the results are shown in table-9.

Table-9. Diagnostic Tests of Model

\begin{tabular}{l|l|l}
\hline LM Version & Coefficient & Probability \\
\hline Serial Correlation & 2.640 & 0.0 .10 \\
\hline Functional Form & 0.221 & 0.638 \\
\hline Normality & $87.248^{*}$ & 0.000 \\
\hline Heteroscedasticity & 7.5464 & 0.006 \\
\hline Normality test is not applicable in ARDL application
\end{tabular}

Diagnostic tests clearly describes that there is no problem of serial correlation and heteroskedasticity. However, the problem of normality of data and heteroscedasticity is diagnosed in the model. Normality is not applicable for ARDL to cointegration and heteroscedasticity does not affect the results of ARDL.

Table-10. Short Run Estimation of $\operatorname{ARDL}(1,0,0,0,0)$

\begin{tabular}{l|l|l|l}
\hline Variables & Coefficients & t- statistics & p- values \\
\hline $\mathrm{dFDI}$ & 0.0004 & 0.1897 & 0.851 \\
\hline $\mathrm{dEXR}$ & 0.0339 & $1.861^{* * *}$ & 0.071 \\
\hline $\mathrm{dGDPD}$ & -0.150 & -1.505 & 0.141 \\
\hline $\mathrm{dSSI}$ & -4.631 & $-4.769^{*}$ & 0.000 \\
\hline $\mathrm{ECM}(-1)$ & -0.579 & -4.845 & 0.000 \\
\hline F statistics $=6.2235$ & Probability $=0.001$ & $\mathrm{R}-\mathrm{Squared}=0.42$ \\
$\mathrm{R}-$ Bar-Squared $=0.354$ & DW-statistic $=2.0515$ & \\
*, ** and *** represents 1,5 and 10 percent level of significance respectively
\end{tabular}

Error correction term ECM (-1) that is obtained from long run analysis explains that in short run how much disequilibrium will move away in the long run. The error correction term is found negative and highly significant. The value of ECM (-1) coefficient is -0.57 which means that every year $57 \%$ divergence from long run inequality is corrected. In other words, we can say that the adjustment to equilibrium procedure is fast from previous year to the current year. F-statistic value is 6.22 with probability of 0.001 which shows the overall significance of the model. Error correction test shows that exchange rate (EXR) and socioeconomic stability index (SSI) play a significant role in the volatility of stock prices. In the short run, the behavior of exchange rate is positive for stock price 
variability. The socioeconomic stability affects the variability of stock prices negatively which means that positive change in socioeconomic indicators lead to decrease the volatility of stock market prices in short run.

The stability of the model is tested by cumulative sum (CUSUM) and cumulative sum of squares (CUSUMSQ) tests. The results are shown in figure 4 and 5 .

\section{Plot of Cumulative Sum of Recursive Residuals}

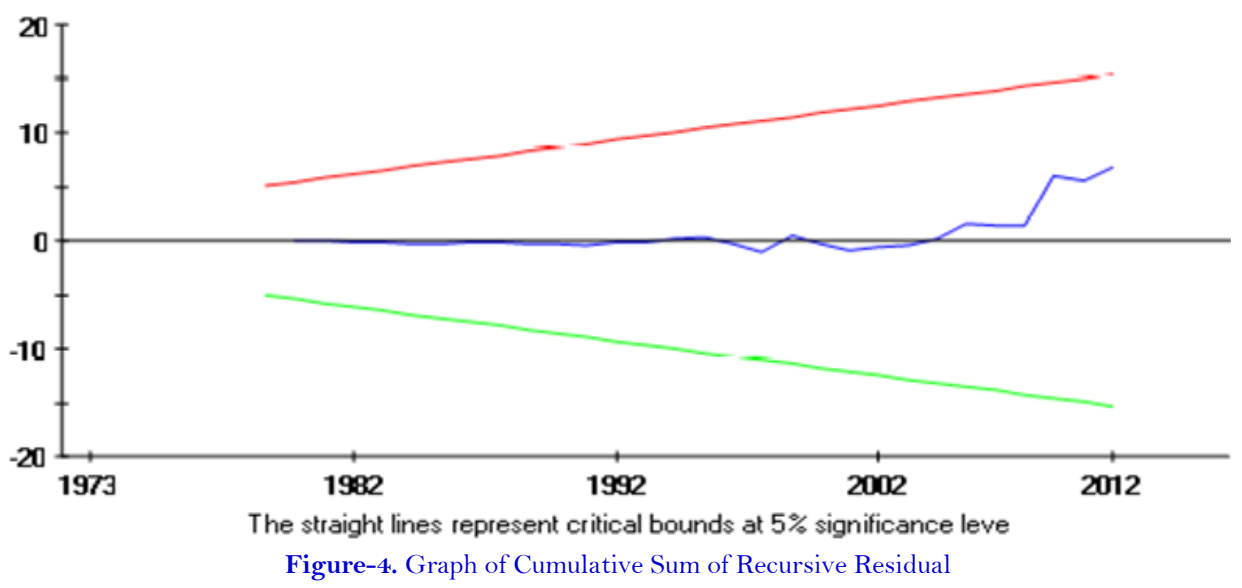

\section{Plot of Cumulative Sum of Squares of Recursive Residuals}

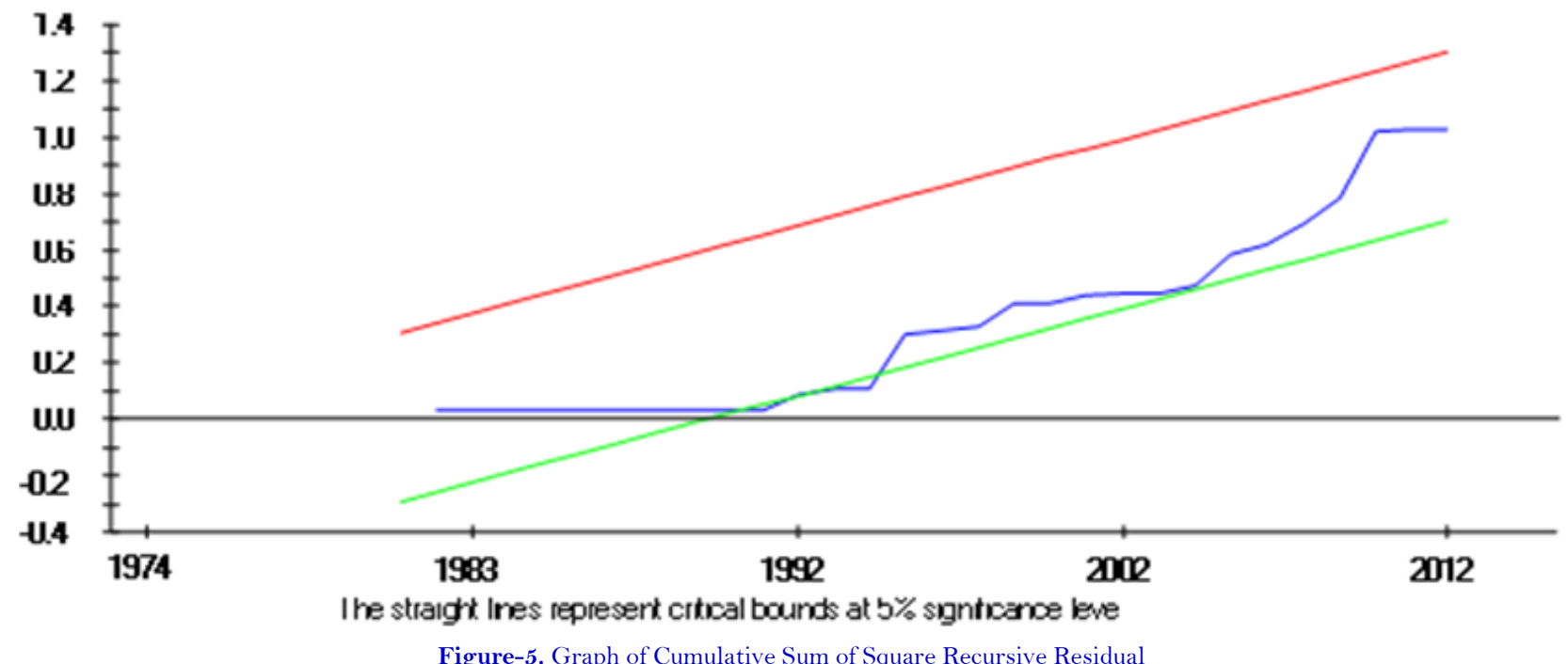

The figure 4 verified that CUSUM line is between the upper and lower bounds which show that the model is stable in parameters. Figure 5 represents the CUSUM square of residuals which shows that the estimated line remained within the critical bounds at 5 percent level of significance yet it touches the lower bound two times. The first point is relevant with the 1991 financial reforms in Pakistan along with the period of political instability in Pakistan, i.e. frequent change of governments in this period. Afterwards the privatization and denationalization policies made the variability of stock market prices to start rising rapidly. The second point related with 9/11 attacks in 2001 which disturbed the financial markets all over the world. United States intervention in Afghanistan created uncertainty in financial market of Pakistan.

To check the structural breaks, chow test of break points has been used for specific years. We found no structural breaks except years 2003 to 2006. Test results are given in table-11. 
Chow Breakpoint Test: 2003

Null Hypothesis: No breaks at specified breakpoints

Varying regressors: All equation variables

\begin{tabular}{l|l|l|l}
\hline F-statistic & 3.100750 & Prob. F (4,31) & 0.0295 \\
\hline Log likelihood ratio & 13.12511 & Prob. Chi-Square (4) & 0.0107 \\
\hline Wald Statistic & 12.40300 & Prob. Chi-Square (4) & 0.0146 \\
\hline
\end{tabular}

Chow Breakpoint Test: 2004

Null Hypothesis: No breaks at specified breakpoints

Varying regressors: All equation variables

Equation Sample: 19732012

\begin{tabular}{l|l|l|l}
\hline F-statistic & 3.198617 & Prob. F $(4,31)$ & 0.0202 \\
\hline Log likelihood ratio & 17.12930 & Prob. Chi-Square (4) & 0.0043 \\
\hline Wald Statistic & 15.99308 & Prob. Chi-Square (4) & 0.0069
\end{tabular}

Chow Breakpoint Test: 2005

Null Hypothesis: No breaks at specified breakpoints

Varying regressors: All equation variables

Equation Sample: 19732012

\begin{tabular}{l|l|l|l}
\hline F-statistic & 5.048941 & Prob. F (4,31) & 0.0019 \\
\hline Log likelihood ratio & 24.42217 & Prob. Chi-Square (4) & 0.0002 \\
\hline Wald Statistic & 25.24471 & Prob. Chi-Square (4) & 0.0001 \\
\hline
\end{tabular}

Chow Breakpoint Test: 2006

Null Hypothesis: No breaks at specified breakpoints

Varying regressors: All equation variables

Equation Sample: 19732012

\begin{tabular}{l|l|l|l}
\hline F-statistic & 11.42558 & Prob. F (4,31) & 0.000 \\
\hline Log likelihood ratio & 35.33185 & Prob. Chi-Square (4) & 0.000 \\
\hline Wald Statistic & 45.70233 & Prob. Chi-Square (4) & 0.000 \\
\hline
\end{tabular}

\section{CONCLUSION}

The objective of the study was to measure the impact of socioeconomic stability and macroeconomic factors on volatility of stock prices in Pakistan. The explanatory variables include socioeconomic stability, inflation, exchange rate and foreign direct investment. The Karachi Stock Exchange was taken as a representative stock exchange of Pakistan.

The ARDL results have shown that in Pakistan foreign direct investment positively affects stock prices in the long run. The results match with the findings of Raza et al. (2012). The exchange rate affects stock prices negatively in the long run. The finding is consistent with Raza et al. (2012). Inflation has positive effect in long run (Nishat $e t$ al., 2004; Akbar et al., 2012; Raza et al., 2012). It is because in the long run, people are confident about future expected inflation so their behavior does not act to create more volatility in stock prices.

Socioeconomic stability negatively affects the variability in stock prices in the long run. The result showed that socioeconomic instability increases variability in stock market prices that loose the confidence of investors. The study proposed that public sector managers should take steps to ensure the socioeconomic stability in the economy so that economic growth rate may be enhanced through stable stock market.

Funding: This study received no specific financial support.

Competing Interests: The authors declare that they have no competing interests.

Contributors/Acknowledgement: All authors contributed equally to the conception and design of the study.

\section{REFERENCES}

Akbar, M., S. Ali and M.F. Khan, 2012. The relationship of stock prices and macroeconomic variables revisited: Evidence from Karachi stock exchange. African Journal of Business Management, 6(4): 1315-1322.Available at: https://doi.org/10.5897/ajbm1 1.1043 
Ali, M.B., 2011. Impact of micro and macroeconomic variables on emerging stock market return: A case on Dhaka stock exchange (DSE). Interdisciplinary Journal of Research in Business, 1(5): 8-16.

Asaolu, T. and M. Ogunmuyiwa, 2011. An econometric analysis of the impact of macroecomomic variables on stock market movement in Nigeria. Asian Journal of Business Management, 3(1): 72-78.

Azam, M., 2011. Stock price variation regarding macroeconomic and firm-specific accounting variables: Evidence from Karachi stock exchange. International Research Journal of Finance and Economics, 81: 77-88.

Azam, M. and D. Kumar, 2011. Factors influencing the individual investor and stock price variation: Evidence from Karachi stock exchange. Australian Journal of Basic and Applied Sciences, 5(12): 3040-3043.

Beaulieu, M.-C., J.-C. Cosset and N. Essaddam, 2005. The impact of political risk on the volatility of stock returns: The case of Canada. Journal of International Business Studies, 36(6): 701-718.Available at: https://doi.org/10.1057/palgrave.jibs.8400160.

Bollerslev, T., 1986. Generalized autoregressive conditional heteroskedasticity. Journal of Econometrics, 31(3): 307327.Available at: https://doi.org/10.1198/073500102288618487.

Engle, R.F., 1982. Autoregressive conditional heteroscedasticity with estimates of the variance of United Kingdom inflation. Econometrica: Journal of the Econometric Society, 50(4): 987-1007.Available at: https://doi.org/10.2307/1912773.

Fama, E.F., 1970. Efficient capital markets: A review of theory and empirical work. The Journal of Finance, 25(2): 383417.Available at: https://doi.org/10.2307/2325486.

Fama, E.F., 1990. Stock returns, expected returns, and real activity. The Journal of Finance, 45(4): 1089-1 108.Available at: https://doi.org/10.2307/2328716.

Gan, C., M. Lee, H.H.A. Yong and J. Zhang, 2006. Macroeconomic variables and stock market interactions: New zealand evidence. Investment Management and Financial Innovations, 3(4): 89-101.

Grossman, S.J. and R.J. Shiller, 1981. The determinants of the variability of stock market prices. The American Economic Review, $71(2)$ : 222-227.

Humpe, A. and P. Macmillan, 2007. Can macroeconomic variables explain long term stock market movements? A comparison of the US and Japan. Centre for Dynamic Macroeconomic Analysis. Working Paper Series CDMA 07/20.

Khan, R.E.A. and S. Ullah, 2014. Measuring the governance in Pakistan: An introduction to the KU index // measuring governance in Pakistan: Presenting the KU index. Acta Economica, 12(21): 23-41.

Menike, L.M.C., 2003. The effect of macroeconomic variables on stock prices in emerging Sri Lankan stock market. Sabaragamuwa University Journal, 6(1): 50-67.Available at: https://doi.org/10.4038/suslj.v6i1.1689.

Mukherjee, T.K. and A. Naka, 1995. Dynamic relations between macroeconomic variables and the Japanese stock market: An application of a vector error correction model. Journal of Financial Research, 18(2): 223-237.Available at: https://doi.org/10.1111/j.1475-6803.1995.tbo0563.x.

Nishat, M., R. Shaheen and S.T. Hijazi, 2004. Macroeconomic factors and the Pakistani equity market [with Comments]. The Pakistan Development Review, 43(4): 619-637.Available at: https://doi.org/10.30541/v43i4iipp.619-637.

Pesaran, H.M. and Y. Shin, 1999. An autoregressive distributed lag modeling approach to cointegration analysis. In Strom, S. (ed.), Econometrics and Economic Theory in the 20th Century: The Ragnar Frisch Centennial Symposium. Cambridge: Cambridge University Press.

Pesaran, M.H., Y. Shin and R.J. Smith, 2001. Bounds testing approaches to the analysis of level relationships. Journal of Applied Econometrics, 16(3): 289-326.Available at: https://doi.org/10.1002/jae.616.

Phillips, P.C. and P. Perron, 1988. Testing for a unit root in time series regression. Biometrika, 75(2): 335-346.Available at: https://doi.org/10.2307/2336182.

Raza, A., N. Iqbal, Z. Ahmed, M. Ahmed and T. Ahmed, 2012. The role of FDI on stock market development: The case of Pakistan. Journal of Economics and Behavioral Studies, 4(1): 26-33.

Rotberg, R.I. and R.M. Gisselquist, 2009. Strengthening African Governance: Index of African Governance Results and Rankings, Harvard Kennedy School 79 John F. Kennedy Street, Box 121 Cambridge, MA. 02138 October. 
Rukh, L., K. Ahmed, H. Bilal, S. Khan and Z. Khan, 2011. Effect of discount rate, T-bills and CPI on trading volume of KSE- 30 and 100 indexes. Asian Journal of Business and Management Sciences, 10(1): 25-34.

Zaidi, S.A., 2010. Issues in Pakistan’s economy. Karachi: Oxford University Press. 